\title{
Use of gene targeting for compromising energy homeostasis in neuro-muscular tissues: The role of sarcomeric mitochondrial creatine kinase
}

\author{
Karen Steeghs ${ }^{a}$, Arend Heerschap ${ }^{b}$, Amold de Haan ${ }^{c}$, Wim Ruitenbeek ${ }^{d}$, Frank Oerlemans ${ }^{\text {, }}$ \\ Jan van Deursen ${ }^{\mathrm{e}}$, Benjamin Perryman ${ }^{\mathrm{f}}$, Dirk Pette ${ }^{\mathrm{g}}$, Marloes Brückwilder ${ }^{\mathrm{d}}$, \\ Jolande Koudijs ${ }^{\mathrm{c}}$, Paul Jap ${ }^{\mathrm{a}}$, Bé Wieringa ${ }^{\mathrm{a}, *}$ \\ a Department of Cell Biology and Histology, Faculty of Medical Sciences, University of Nijmegen, P.O. Box 9101, 6500 HB Nijmegen. Netherlands \\ ${ }^{\circ}$ Department of Diagnostic Radiology, Faculty of Medical Sciences, University of Nijmegen, P.O. Box 9101, 6500 HB Nijmegen. Netherlands \\ 'Department of Muscle and Exercise Physiology, Vrije University, Van der Boechorststraat 9. 1081 BT Amsterdam, Netherlands \\ ${ }^{d}$ Department of Paediatrics, Faculty of Medical Sciences, University of Nijmegen, P.O. Box 9J01, 6500 HB Nijmegen, Netherlands \\ 'Department of Genetics, St. Jude Children's Research Hospital, P.O. Box 318, Memphis, TN 3810I, USA \\ 'Division of Cardiology, University of Colorado Health Sciences Center, Denver, CO 80262, USA \\ Department of Biology, University of Konstanz, P.O. Box 5560 / M641. Konstanz D-7834, Germany
}

\begin{abstract}
We have introduced a single knock-out mutation in the mitochondrial creatine kinase gene ( $\mathrm{ScCKmit)}$ in the mouse germ line via targeted mutagenesis in mouse embryonic stem (ES) cells. Surprisingly, ScCKmit - / - muscles, unlike muscles of mice with a deficiency of cytosolic M-type creatine kinase (M-CK - /-; Van Deursen et al. (1993) Cell 74, 621-631), display no altered morphology, performance or oxidative phosphorylation capacity. Also, the levels of high energy phosphate metabolites were essentially unaltered in ScCKmit mutants. Our results challenge some of the present concepts about the strict coupling between CKmit function and aerobic respiration.
\end{abstract}

Keywords: Creatine kinase; Mitochondria; Gene targeting; Energy homeostasis; Muscle physiology; Oxidative phosphorylation

\section{Introduction}

The flux of high energy phosphoryl groups between cellular sites of ATP production and utilization is controlled by the coupling of highly organized multienzyme systems which create an optimal microenvironment for efficient substrate and product channeling. Through such coupled systems high reaction rates can be achieved independently of the average concentration of high-energy metabolites (i.e., ATP) in the cytoplasm (Srere, 1987). This is especially important for tissues with large and sudden fluctuations in the use and synthesis of ATP, such as nerve and muscle. One of the cellular systems involved in maintenance of the proper energy balance comprises the family of creatine kinase isoenzymes (CKs), which catalyse the reversible exchange of high-energy phosphate be-

\footnotetext{
"Corresponding author. Tel.: + 31 (24) 3614287; Fax: int. + 31 (24) 3540525 .
}

tween ATP and phosphocreatine ( $\mathrm{PCr}): \mathrm{MgADP}^{-}+\mathrm{PCr}^{2-}$ $+\mathrm{H}^{+} \Leftrightarrow \mathrm{MgATP}^{2-}+\mathrm{Cr}$ (Fig. 1, Bessmann and Carpenter, 1985; Wallimann et al., 1992). In birds and mammals, five $\mathrm{CK}$ isoenzymes have been identified which are expressed tissue-specifically, and vary with regard to their intracellular (sub)localization. Three of the five CKs are cytosolic enzymes which exist as dimers composed of the $M$ (for muscle) and B (for brain) subunits (Fig. 1). They assemble into the homodimeric CKMM and CKBB, or heterodimeric CKMB isoenzymes, with molecular masses varying from 80 to $86 \mathrm{kDa}$. CKMM is predominantly found in mature skeletal and cardiac muscle. CKBB activity is highest in brain and neural tissue, embryonic cardiac and skeletal muscle, and in a large array of cells with very specialized functions such as photoreceptor cells of the retina, spermatozoa, smooth muscle cells, placenta, and epithelial cells of uterus, kidney and intestine (Wallimann et al., 1992; Ikeda, 1988; Friedman and Perryman, 1991; Ishida et al., 1994). The CKMB isoform is mainly found during embryonic development of striated muscle when a 
(a)

Sites of

ATPase activity

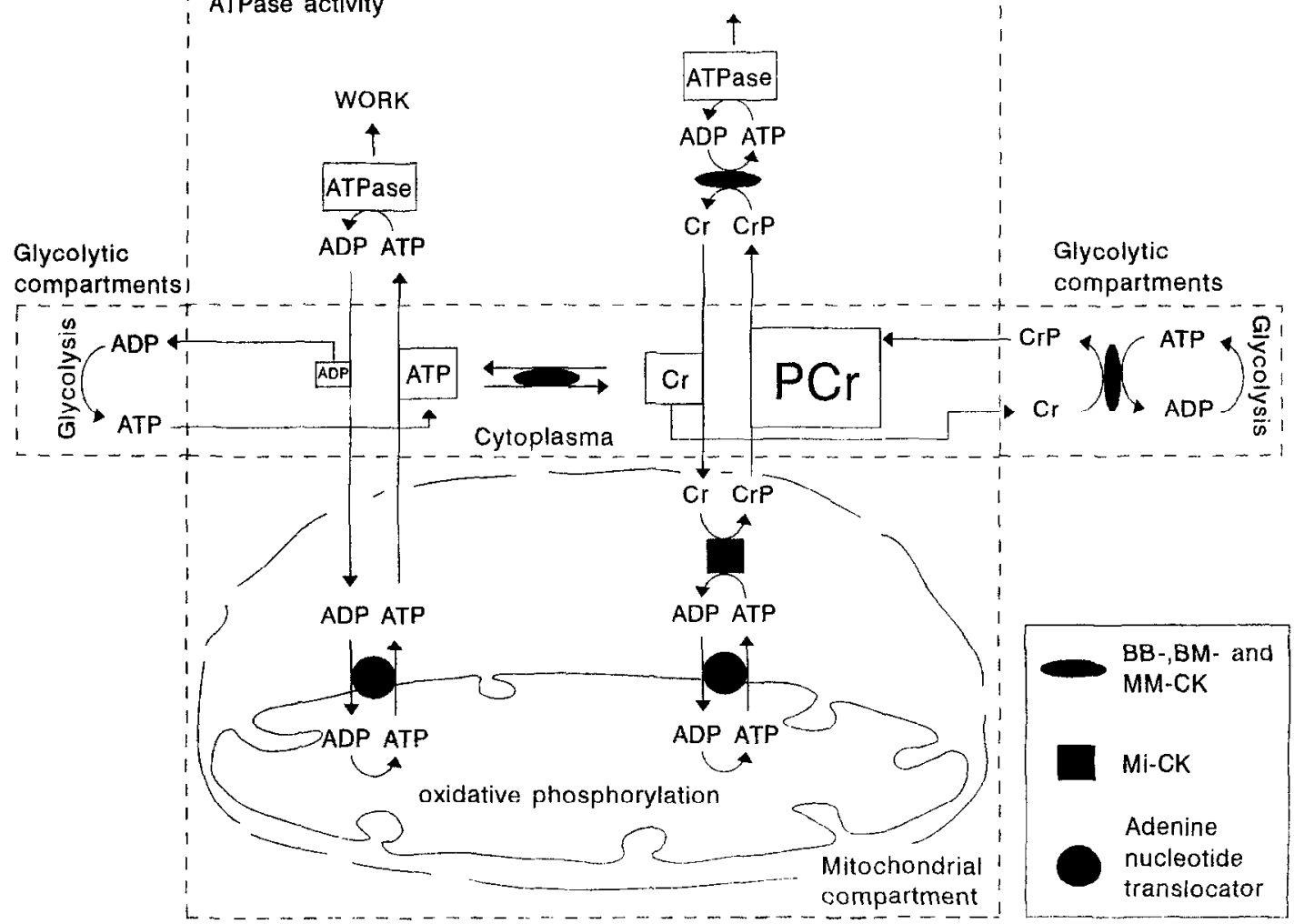

(b)
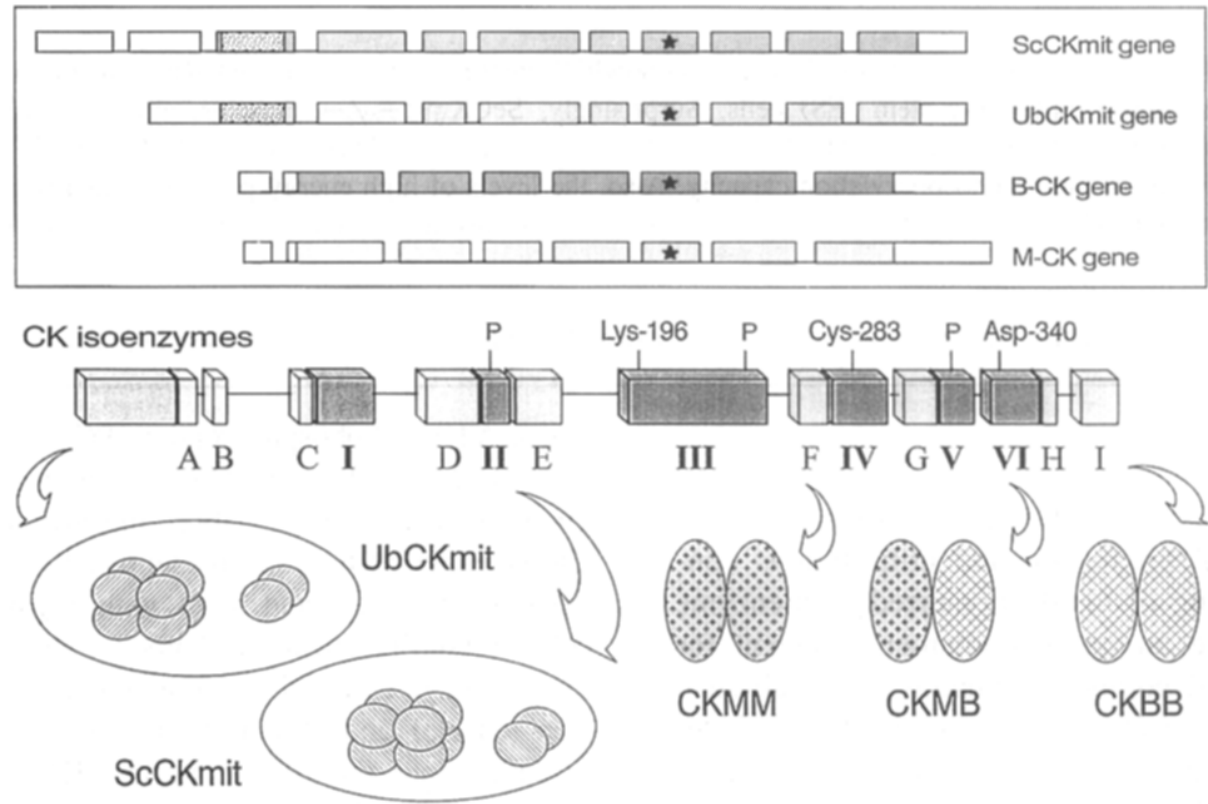

Fig. 1. The CK/PCr system in cellular energy metabolism (A) and genes and proteins of the CK isoenzyme family (B). (A) The CK/PCr system and its relation to pathways for energy supply are represented schematically. The major cellular compartments involved in the energy metabolism are drawn within dashed lines. The boxes depicted in the cytoplasm represent the freely exchangeable pools of $\mathrm{PCr}, \mathrm{Cr}, \mathrm{ATP}$ and ADP in this compartment. The size of the individual pools is very much dependent on the tissue and cell type. ATPases may represent the myofibrillar actin-activated Mg ${ }^{2+}-\mathrm{ATPase}$, the plasma membrane or sarcoplasmic reticulum $\mathrm{Ca}^{2+}$-ATPases, or $\mathrm{Na}^{+} / \mathrm{K}^{+}$-ATPases. The adenylate kinase (AK) system which provides a parallel and partially overlapping system for high energy phosphoryl exchange reactions is not shown here. (B) Four functional nuclear genes encode the individual CK subunits, Exons of the genes (drawn on scale) are depicted as boxes; lengths of introns (which vary considerably and are much targer in the M-CK and ScCKmit genes than in the B-CK and UbCKmit genes) have not been considered and are therefore not given according to scale. Untranslated regions are blank, coding sequences of all genes are in solid grey, and the regions of the CKmit genes encoding the mitochondrial targeting sequences are dotted. Asterisks mark the only exon that is shared between all CK genes. In the translated CK peptide shown, six blocks (I-VI) constitute the CK framework, while 9 domains (A-I) are specific for cytosolic or mitochondrial CKs, or for one of the four subtypes. The first block at the N-terminus is the mitochondrial targeting peptide which is proteolytically removed after mitochondrial import. Finally, the individual subunits assemble into enzymatically active proteins in the cytosolic and mitochondrial compartments. Data from Mühlebach et al. (1994) served as basis for this figure. 
transition from CKBB to the CKMM isoforms takes place (Perriard et al., 1989; Trask et al., 1988), and in the adult mammalian heart. The remaining two $\mathrm{CK}$ isoforms are distinct subtypes which are specifically located in the mitochondrial intermembrane space: the ubiquitous (UbCKmit) and sarcomeric (ScCKmit) CKmit enzymes (Jacobus and Lehninger, 1973; Hossle et al., 1988). Typically, the ScCKmit is expressed in striated muscle tissue, in conjunction with M-CK subunits, while UbCKmit is expressed in those cells and tissues where B-CK is active (Wallimann et al., 1992; Wyss et al., 1992). Upon entry in mitochondria their $\mathrm{N}$-terminal import signal is removed and the mature CKmit subunits assemble into stable 75-89 $\mathrm{kDa}$ dimeric and 317-377 $\mathrm{kDa}$ octameric molecules (Mühlebach ct al., 1994; Hossle ct al., 1988; Haas et al., 1989; Payne et al., 1991). Here they concentrate at contact sites where the outer and inner membranes are in close apposition (Adams et al., 1989). It is likely that the dynamics of mitCK octamer/dimer formation and the association to these sites in vivo (Knoll and Brdiczka, 1983; Lipskaya and Trofimova, 1989; Biermans et al., 1990; Brdiczka, 1991; Brdiczka and Wallimann, 1994; Schlegel et al.. 1990; Rojo et al., 1991) are influenced in response to varying energy demands and are important physiological mechanisms for regulating the enzyme's catalytic properties, the high-energy phosphoryl flux into the cytosol (Veksler and Ventura-Clapier, 1994; Saks et al., 1994), and the OXPHOS and glycolytic activity of cells (Erecinska and Wilson, 1982; Balaban, 1990; Scopes, 1973). In these reaction cascades the ADP $\Leftrightarrow$ ATP + AMP exchange mediated by adenylate kinases may also be involved (Gellerich, 1992; Savabi, 1994). Furthermore, in the cytoplasmic space, CKs assist in the compartmentalizalion of ATP and ADP (Jones, 1986; Miller and Horowitz, 1986). In muscle, CKMM mediated ATP production is coupled to the local activity of SR- and plasma-bound $\mathrm{Ca}^{2+}$-ATPases (Levitsky et al., 1978; Rossi et al., 1990; Korge and Campbell, 1994), the $\mathrm{Na}^{+} / \mathrm{K}^{+}$-ATPase (Saks et al., 1977: Grosse et al., 1980) and the myosin ATPase involved in actin-myosin sliding during contraction (Wegmann et al.. 1992; Turner et al., 1973; Saks et al., 1976; Ventura-Clapier et al., 1987, 1994. Likewise, the coupling to $\mathrm{CKBB}$ may be of functional importance for the action of $\mathrm{Na}^{+} / \mathrm{K}^{+}$-ATPase in specialized cell types with the brain. kidney and many other tissues (Hemmer and Wallimann, 1993: Friedman and Roberts, 1994). Furthermore, there are suggestions that the $\mathrm{CK} / \mathrm{PCr}$ system (via $\mathrm{B}-\mathrm{CK}$ ) may play a role in neurotransmitter release, the maintenance of membrane potentials, restoration of ionic gradients in neurons, spatial $\mathrm{K}^{+}$buffering in Bergmann glial cells, metabolic interactions between astrocytes and neurons. myelin synthesis by oligodendrocytes, and restoring $\mathrm{K}^{+}$ion gradients in glomerular structures in the cerebellum (Friedhof and Lemer, 1977; Lim et al., 1989; Blum et al., 1991; Reichenbach, 1991; Hemmer and Wallimann, 1993: Hemmer al. 1994).
In order to obtain a better understanding of the subcellular partitioning of components of the $\mathrm{CK} / \mathrm{PCr}$ system, and to unravel its role in the compartmentalization of energy homeostasis in different cell types, it will become of utmost importance to apply experimental methods which preserve the integrity of the cells delicate organization, and the communication between specific cellular 'aggregulons' or microcompartments. Fortunately, the rapid development of techniques to manipulate gene expression in vivo, in cells and experimental animals, is providing us with powerful new tools for these kind of studies. Normal or mutant genes of interest can be either overexpressed, or their expression can be directed to specific tissues using 'conventional' transgenesis by micro-injecting DNA into the fertilized egg (Jaenisch, 1988). In an alternative approach, gene targeting in mouse embryonic stem (ES) cells creates the possibility to produce mice carrying predesigned mutations in the germline (Thomas and Capecchi, 1987). This sophisticated technique, mostly applied as a gene 'knock out' mutagenesis method, has already been used to generate over 400 new mouse lines (Brandon et al., 1995) and is currently one of the methods of choice for revealing unknown gene functions, and for understanding gene functions in the context of the whole animal (see Capecchi. 1989; Evans, 1989: Joyner, 1991: Rossant. 1991: Smithies. 1993 for review). We and others have applied the methodology for altering the expression levels of the different $\mathrm{CK}$ isoenzymes in vivo. Transgenic techniques have been applied to direct B-CK and UbCKmit isoenzyme expression to mouse liver, as well as to induce ectopic B-CK expression in striated muscle tissue (Koretsky et al., 1990; Brosnan et al., 1990. 1993). Our group has generated mice completely deficient in M-CK subunits and mice expressing reduced levels of $\mathrm{M}-\mathrm{CK}$ by gene targeting. The biolog. ical consequences of these mutations have been characterised (Van Deursen et al., 1993, 1994a,b). Likewise. animals with a deficiency in the ubiquitous mitochondrial CK subform (UbCKmit). with surprisingly little phenotypic effects, have been generated (Steeghs et al., 1995a,b). Here, as an illustration of the potential usefulness of the methodology, we address specifically the role of the sarcomeric mitochondrial CK (ScCKmit) reaction and report on the biochemical, physiological and morphological consequences of knock-out of the ScCKmit gene. As the effects are anexpectedly mild, some of the simplified concepts for the role of the $\mathrm{CK}$ system in energy delivery to muscle may need revision, and are challenged in the discussion.

\section{Experimental procedures}

\subsection{Construction of the targeting vector}

An EMBL3 phage library of partially digested genomic DNA of the 129/Sv mouse strain (D'Azzo and Grosveld. 
A

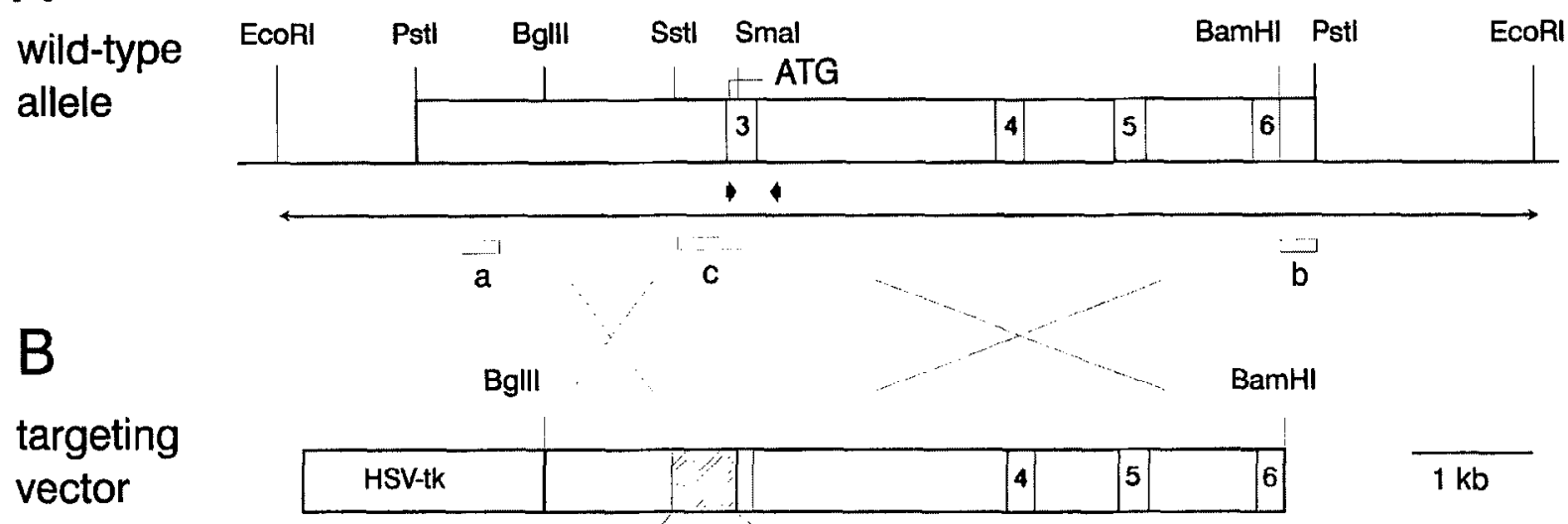

C

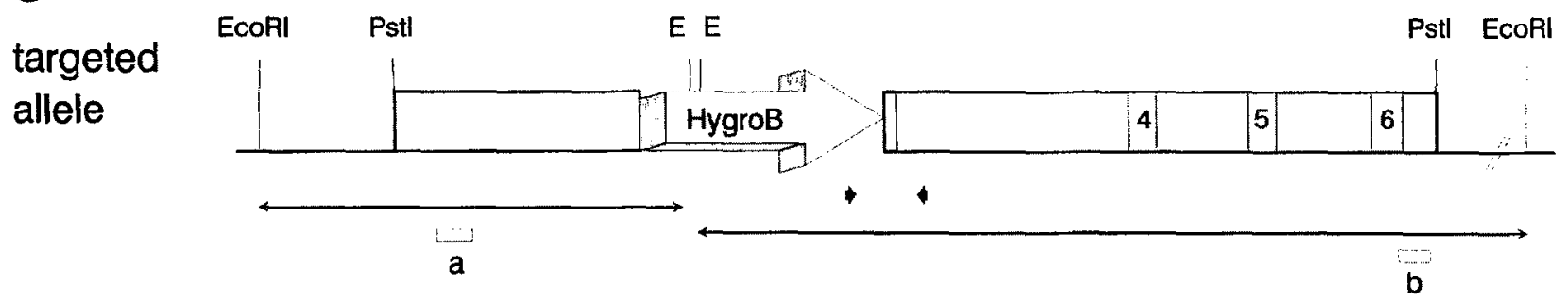

D $\quad E_{n t}^{14}+\%+\%$
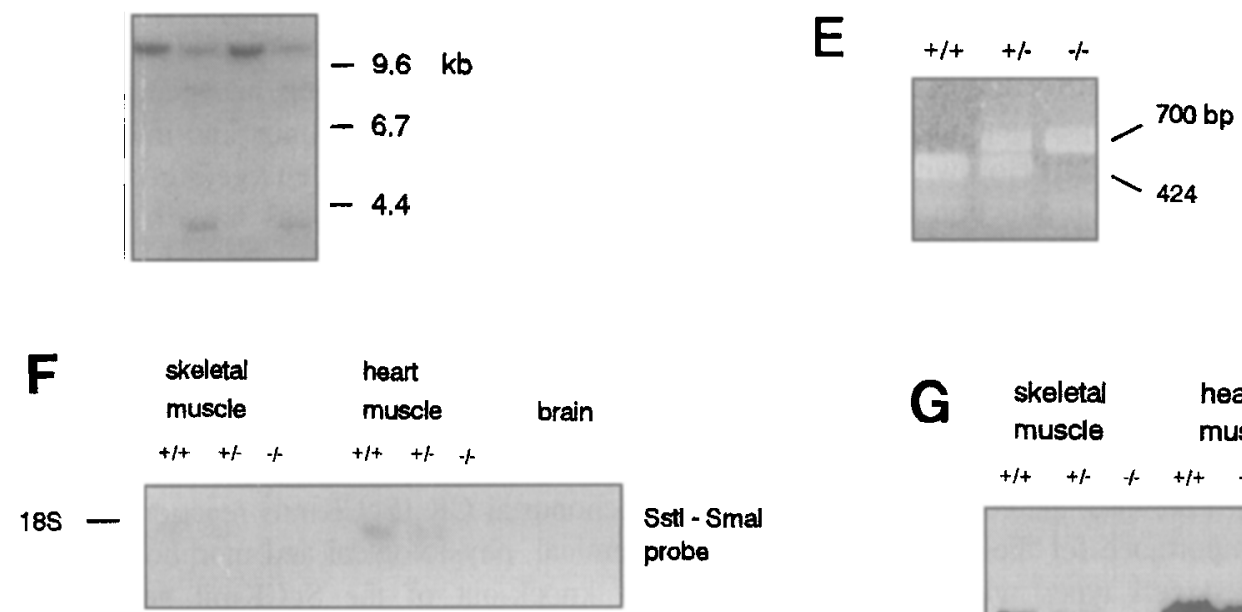

Sst - Smal probe

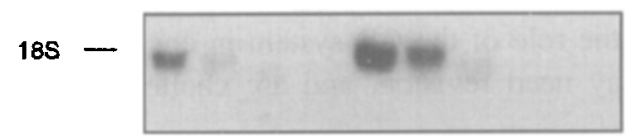

ScCKmit exon 3-4 CDNA probe
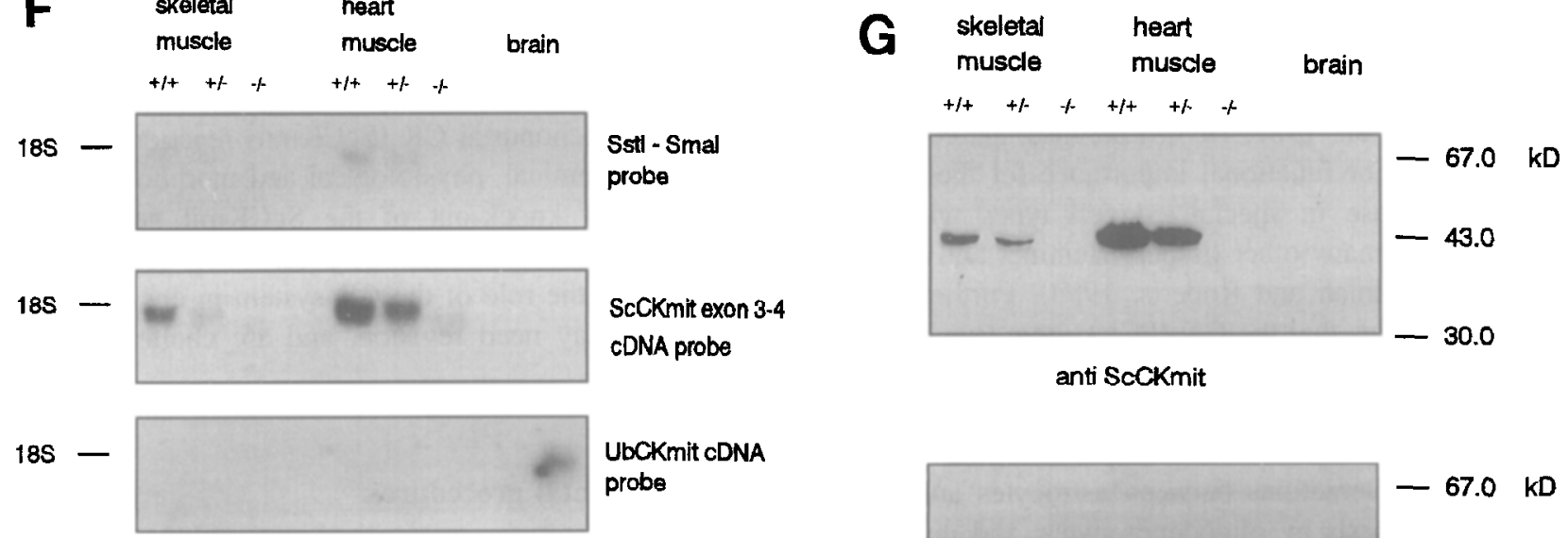

UbCKmit cDNA probe

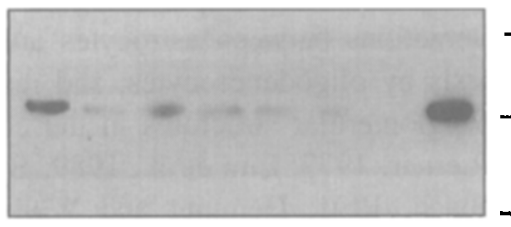

$-67.0 \mathrm{kD}$

185

GAPDH probe

anti UbCKmit 
unpublished) was screened using a $2.1 \mathrm{~kb}$ fragment containing the complete mouse ScCKmit cDNA. Eight positive phages were purified to homogeneity and a common 7 kb Pst I fragment comprising amino acid positions 1-185 of the mature protein (including the $39 \mathrm{~N}$-terminal residues of the mitochondrial transit peptide) was subcloned into plasmid pGEM3 (Promega). To construct a replacement type of targeting vector, a $0.4 \mathrm{~kb}$ Sst I-Smal fragment, encompassing parts of intron 2 and exon 3 and including the ATG translation start codon, was deleted from this genomic clone and replaced by a $2.0 \mathrm{~kb}$ blunt-ended cassette carrying the hygromycin $B$ resistance (hygro $B^{r}$ ) gene (Van Deursen et al., 1992). A cassette containing a $2.0 \mathrm{~kb}$ herpes simplex virus thymidine kinase gene (Van Deursen et al., 1994a,b) was introduced in the upstream BglII site (Fig. 2). The targeting vector was linearized at the most 3' located BamHI site prior to ES cell electroporation.

\subsection{ES cell culture, transfection, and selection}

Wild-type E14 ES cells (kindly provided by Dr. Plump, Rockefeller University, New York, NY) were cultured on a layer of irradiated (3000 rad) SNLH9 feeder cells (Van Deursen et al., 1992) and electroporated essentially as described (Steeghs et al., 1995a,b). ES cells were resuspended in culture medium (at $1.8 \times 10^{7}$ cells $/ \mathrm{ml}$ in 0.8 ml) mixed with $20 \mu \mathrm{g}$ of BamHI-linearized DNA and electroporated at $500 \mu \mathrm{F}$ and $250 \mathrm{~V}$ (Bio-Rad Gene Pulser) before plating on two $10-\mathrm{cm}$ dishes containing irradiated feeder cells. Positive-negative selection was applied for 8-10 days, starting $24 \mathrm{~h}$ after electroporation, with 300 $\mu \mathrm{g} / \mathrm{ml}$ hygromycinB (ICN Biomedicals, Aurora, Ohio) and $0.2 \mathrm{mM}$ FIAU (1-[2'-deoxy-2'-f]uoro- $\beta$-Darabinofuranosyll-5-iodouridine, kindly provided by Bristol Meyers).

\subsection{Generation of ScCKmit deficient mice}

Expanded E14 clones showing genuine recombination events were cytogenetically typed and ultimately $8-12$ cells from six independent clones were injected into recipient C57BL/ 6 blastocysts, and implanted into the uterine horns of pseudopregnant foster mothers (Bradley, 1987). The resulting chimaeric males were mated with $\mathrm{C} 57 \mathrm{BL} / 6$ females to score for germline transmission of the mutation and offspring heterozygous for the mutant ScCKmit allele were identified by Southern blot analysis. Genotypes of pups resulting from crosses between heterozygotes were PCR analyzed and ScCKmit null mutants (ScCKmit $[-/-]$ ) from one ES cell line were selected for further breeding.

\subsection{Genomic DNA analysis}

Genomic DNA from ES cells or mouse tail biopsics was isolated and used for Southern blot analysis following standard procedures as described (Steeghs et al., 1995b). Probes to identify targeting events were a 500 bp Haelll Apal fragment at the 5 side and a $300 \mathrm{bp} \mathrm{BamHI-P_{stl }}$ fragment at the $3^{\prime}$ side (see Fig. 2). PCR was used for genotyping offspring using three primers in one reaction mixture. Forward primers were $\mathrm{Scl}$ located in exon 3 (5'-AAGAGGAAGGATGGCCAGTGCC-3') and $\mathrm{Hl}$ located in the hygroB ${ }^{\circ}$ gene $\left(5^{\prime}\right.$-GGCTGGCACTCTGTCGATACCC- $\left.3^{\prime}\right)$. Sc2 is the reverse primer located in intron $3\left(5^{\prime}\right.$-AATTCCCAGCACTCACACGGCA-3 $\left.3^{\prime}\right)$ of the ScCKmit gene. Following an initial denaturation step $\left(96^{\circ} \mathrm{C}\right.$ for $\left.1 \mathrm{~min}\right) 30$ consecutive cycles of $\mathrm{PCR}$, in $50-\mu]$ volumes containing $10 \mathrm{mM}$ Tris- $\mathrm{HCl} \mathrm{pH}$ $8.3,50 \mathrm{mM} \mathrm{KCl}, 1.5 \mathrm{mM} \mathrm{MgCl}, 0.01 \%$ gelatin, $100 \mathrm{ng}$ of each primer, $100 \mathrm{ng}$ DNA template and I U Ampli$\mathrm{Taq}^{\text {Th }}$ DNA polymerase (Perkin Elmer Cetus), were per-

Fig. 2. Targeted disruption of the mouse ScCKmit gene and analysis of the effect of mutation at the DNA, RNA and protein level in CK-mutant tissues. Schematic diagrams show (A) the genomic structure of the wild-type ScCKmit gcne, (B) the structure of the targeting vector, and (C) the predicted structure of the targeted ScCKmit allele. Numbers denote exons 3-6; ATG indicates the translation initiation site. The arrowed lines represent the diagnostic EcoRI fragments in the wild-type and mutated allele. Stretches of homology between targeting vector and the endogenous ScCKmit locus encompass $1.0 \mathrm{~kb}$ at the $5^{\prime}$, and $4.2 \mathrm{~kb}$ at the $3^{\prime}$ end. Homologous recombination events at the ScCKmit locus were identified using a $500 \mathrm{bp} \mathrm{Haelll-Apal}$ fragment (a) and a 300 bp BamHI-Pst fragment (b) as probes for the $5^{\prime}$ and $3^{\prime}$ regions just outside the targeting vector, respectively (solid boxes). Probe $c$ is the 400 bp Sst I-Smal fragment that was replaced in the targeting vector. The small arrows show the position and direction of the oligonucleotide primers used for PCR analysis of mouse tail biopsies. Position and transcriptional orientation of the HygroB cassette is indicated by the large arrow. (D) Southem blot analysis of genomic DNA of wild-type E14 ES cells, two clones correctly targeted at the ScCKmit locus $(+/-)$, and one clone with a random integration $(+/+)$. DNA was digested with $E c o R I$ and the blot was simultaneously hybridized with probes a and $b$. (E) Identification of the genotype of offspring of crosses between mice heterozygous for the mutant ScCKmit allele. Genomic DNA was isolated from tail biopsies and a PCR reaction was performed with three primers (see A,C) to discriminate between wild-type and targeted alleles. Sizes of the DNA fragments in bp are indicated on the right. (F) Northern RNA blot analysis of total hind leg muscle and heart muscle of wild-type $(+/+)$, heterozygous $(+/-)$, and homozygous $(-/-)$ littermates, carrying ScCKmit mutant alleles. Brain RNA of wild-type is shown as a control. Blots are hybridized with the indicated CKmit DNA segments and with the GAPDH control probe. (G) Western blot analysis to assess expression of mitochondrial creatine kinase subunits. ECL enhanced immunoblot signals of total protein extracts from skeletal and cardiac muscles of wild-type, heterozygous and homozygous ScCKmit mutant mice (and wild-type brain extract as a reference for the UbCKmit subunit) using specific anti-ScCKmit and anti-UbCKmit polyclonal antibodies are shown. Positions of marker proteins are indicated on the right. A single ScCKmit gene product, with the expected molecular mass of $\sim 42 \mathrm{kDa}$, is detectable in wild-type and heterozygous striated muscle tissue and is completely absent in mice homozygous for the ScCKmit mutation. 
formed $\left(94^{\circ} \mathrm{C}\right.$ for $1 \mathrm{~min}, 60^{\circ} \mathrm{C}$ for $1 \mathrm{~min}$ and $72^{\circ} \mathrm{C}$ for 2 $\mathrm{min}$ ). The product diagnostic for the wild-type locus is 424 $\mathrm{bp}$; the mutant allele product has a length of $702 \mathrm{bp}$.

\subsection{Northern blot analysis}

Total RNAs from freshly removed skeletal muscle, heart, and brain were extracted using the lithium chlorideurea method and analyzed by Northern blot analysis as described (Steeghs et al., 1995b). RNA blots were hybridized with ${ }^{32} \mathrm{P}$-labeled probes of: (i) the genomic $0.4 \mathrm{~kb}$ Sst I-SmaI fragment that was deleted in the targeting vector; (ii) a fragment of the ScCKmit cDNA covering parts of exons 3 and 4 (bp 50-230 of the cDNA, translation start at +1 ); (iii) a 150 bp fragment specific for the $5^{\prime}$ untranslated region of the mouse ubiquitous CKmit gene (Steeghs et al., 1995b); and (iv) a $1.3 \mathrm{~kb}$ Pst I glyceraldehyde-3phosphate dehydrogenase (GAPDH) cDNA probe of rat.

\subsection{Immunoblot analysis}

For Western blot analysis, freshly frozen tissues of total brain, heart muscle and total hind leg muscle were homogenized at $4^{\circ} \mathrm{C}$ with a teflon-glass Potter-Elvehjem homogenizer in 10 volumes SETH buffer $(250 \mathrm{mM}$ sucrose, $2 \mathrm{mM}$ EDTA, $10 \mathrm{mM}$ Tris- $\mathrm{HCl}$ at pH 7.4, and $50 \mathrm{U} / \mathrm{ml}$ heparin). Approx. $40 \mu \mathrm{g}$ total extract protein was separated on a $10 \%(\mathrm{w} / \mathrm{v})$ SDS-polyacrylamide gel, transferred onto nitrocellulose membrane and processed as previously described (Steeghs et al., 1995a). CKmit protein was detected with subunit-specific polyclonal antibodies raised against synthetic peptides of the ScCKmit or UbCKmit isoforms (Friedman and Perryman, 1991). The ScCKmit specific antibody was used at a dilution of 1:5000 in TBST, and the horse radish peroxidase-conjugated goat-anti-rabbit secondary immunoglobulin $G$ (Amersham Life Sciences) was used at a 1:10000 dilution. Visualization of signal was by ECL chemiluminescence (Boehringer Mannheim GmbH, Germany) and exposure to Kodak X-Omat S1 autoradiography film.

Antibodies were stripped from the membrane by a 30 min incubation in $62.5 \mathrm{mM}$ Tris- $\mathrm{HCl} \mathrm{pH} 6.7,2 \%(\mathrm{w} / \mathrm{v})$ SDS, and $100 \mathrm{mM} \beta$-mercaptoethanol at $50^{\circ} \mathrm{C}$ and the immunodetection with 1:300 diluted $\alpha$ UbCKmit antibody and visualization with secondary antibody was performed as described above.

\subsection{CK isoenzyme activity analysis of tissue extracts}

Extracts for zymogram analysis were prepared and assayed as described (Steeghs et al., 1995a,b).

\subsection{Measurement of mitochondrial enzyme activities}

$600 \times g$ supernatants of homogenates from freshly excised heart $(5 \% \mathrm{w} / \mathrm{v})$ and total hind leg muscles $(20 \%$ $w / v)$ were prepared in SETH buffer at $4^{\circ} \mathrm{C}$. Crude mitochondrial suspensions were prepared by centrifugation at $14000 \times g$, washing the mitochondrial pellet once with SETH-buffer, and suspending the mitochondria in a volume of SETH-buffer corresponding to their volume in the $600 \times g$ supernatant. Cytochrome $c$ oxidase and citrate synthase activities were determined according to the methods of Cooperstein and Lazarow (1951) and Srere (1969), respectively. $\left[1-{ }^{14} \mathrm{C}\right]$ Pyruvate oxidation rates were measured in the presence of malate, with and without ADP (Fischer et al., 1986). ATP and $\mathrm{PCr}$ production from arsenite sensitive pyruvate oxidation was assayed by coupled enzyme reactions, monitoring the increase in NADPH at $25^{\circ} \mathrm{C}$ and $340 \mathrm{~nm}$ (Fischer et al., 1986).

\subsection{Chemical analysis of metabolite concentrations}

For analysis of metabolite concentrations, female mice were anaesthetized with pentobarbitone $(90 \mathrm{mg} / \mathrm{kg}$ bodymass; i.p). Medial gastrocnemius muscles were exposed, immediately clamp frozen in brass tongs precooled with liquid nitrogen, pulverized in a mortar under cooling with liquid nitrogen, and freeze-dried overnight. Metabolites were extracted from portions of $\pm 80 \mu \mathrm{g}$ dry tissue powder in $60 \%(\mathrm{v} / \mathrm{v})$ methanol at $-80^{\circ} \mathrm{C}$ for at least $24 \mathrm{~h}$. Metabolites were separated isocratically with high performance liquid chromatography (HPLC) using RP-18 columns (Hewlett Packard). The eluents for separation of nucleotides consisted of $215 \mathrm{mM}$ phosphate buffer $(\mathrm{pH}$ 6.5), $2.3 \mathrm{mM} t$-butylammonium hydroxysulphate (TBAHS) and $2 \%$ acetonitrile (Sellevold et al., 1986). $\mathrm{PCr}$ and $\mathrm{Cr}$ were separated with a mixture of $14.7 \mathrm{mM}$ phosphate buffer (pH 6.5) and $2.3 \mathrm{mM}$ TBAHS (Dunnett et al., 1991). For quantification of the metabolites a UV detector was used with a wavelength of $254 \mathrm{~nm}$ for the nucleotides and $210 \mathrm{~nm}$ for $\mathrm{PCr}$ and $\mathrm{Cr}$. Glycogen levels were assayed as described (Van Deursen et al., 1993).

\subsection{Histochemistry}

Routine histological and histochemical analysis of muscle sections was performed as described (Van Deursen et al., 1993). For analysis of myosin heavy chain (MHC) composition, several muscles from a wild-type and ScCKmit $[-/-]$ mutant females were isolated. MHC isoforms were separated from crude myosin extracts by gradient polyacrylamide gel electrophoresis and silver-stained gels were evaluated densitometrically, essentially as described by Hämäläinen and Pette (1993).

\subsection{1. ${ }^{31} P-N M R$ spectroscopy}

For in vivo ${ }^{31} \mathrm{P}-\mathrm{NMR}$ spectroscopic analysis, mice were anaesthetized with 1-2\% enflurane in $30 \% \mathrm{O}_{2} / 70 \% \mathrm{~N}_{2} \mathrm{O}$ delivered through a face mask. During experimentation the rectal temperature was monitored and maintained at 36.5 
$\pm 1^{\circ} \mathrm{C} .{ }^{31}$ P-NMR spectra of mouse hind limb muscles were recorded on an Oxford Instruments magnet $(4.3 \mathrm{~T})$, equipped with an S.M.I.S. spectrometer, and working at 73 $\mathrm{MHz}$ for ${ }^{31} \mathrm{P}$-NMR. Probe characteristics and experimental conditions for the ${ }^{31} \mathrm{P}$-NMR spectroscopy at rest and during lower limb muscle contraction, as well as for inversion transfer, were essentially as described previously (Van Deursen et al.. 1993; Heerschap et al., 1988a,b). Phosphorus spectra were obtained by applying nominal $70^{\circ}$ pulses of $16 \mu \mathrm{s}$ to the intact muscle. Inversion transfer experiments were performed with repetition times of $12 \mathrm{~s}$ for ScCKmit $-/-$ ] mice.

\subsection{Measurements of skeletal muscle function}

Female mice (age 2-4 months, bodymass $20-30 \mathrm{~g}$ ) were anaesthetized with pentobarbitone $(90 \mathrm{mg} / \mathrm{kg}$ body mass; i.p.). Additional doses ( $25 \mathrm{mg} / \mathrm{kg}$; i.p.) were applied every $30 \mathrm{~min}$. Medial gastrocnemius muscles were prepared free leaving the attachment to the femur and blood supply intact. Distally, the Achilles tendon, with a piece of the calcaneus bone, was attached to a measuring device as described (De Haan et al., 1989). Body temperature was maintained by placing the mouse on a heated pad and muscle temperature was kept at $35^{\circ} \mathrm{C}$ with a water-saturated air flow. Maximal stimulation (current, $0.2 \mathrm{~mA}$; pulse duration, $50 \mu \mathrm{s}$ ) was applied via the severed sciatic nerve, with only the branch leading to the medial gastrocnemius left intact.

Muscle optimum length $\left(L_{0}\right)$ was first estimated using twitch contractions at different lengths of the muscle-tendon complex. and further assessed using three tetani (duration, $150 \mathrm{~ms}$; stimulation frequency, $100 \mathrm{~Hz}$ ). Subsequently, the muscle performed two fatiguing exercise protocols: One long duration $(5 \mathrm{~s})$ isometric tetanus at $L_{0}$, and a series of 20 repeated isometric contractions (duration $170 \mathrm{~ms}$ ) within $5 \mathrm{~s}$ at $L_{0}$. Force signals were digitized $(1000 \mathrm{~Hz})$ and analyzed for peak force, time to peak force, and half-time of relaxation (time for force to fall from half to a quarter at the end of stimulation; Edwards et al., 1975).

\subsection{Electron microscopy}

Ultrathin sections of various muscles were prepared, double contrasted with uranyl acetate and examined in a Philips electron microscope EM 301 or a JEOL TEM 1010 exactly as described (Van Deursen et al., 1993).

\section{Results}

\subsection{Targeted disruption of the ScCKmit locus}

For disruption of the ScCKmit gene, a targeting vector as shown in Fig. 2B was used. This targeting construct was designed to replace a 400 bp genomic fragment encoding the mitochondrial transit peptide and the first three amino acids of the mature protein with a hygroB ${ }^{r}$ gene. We deliberately chose for removal of this segment to prevent the (hypothetical) formation of truncated protein products with signals for import into mitochondria. thus avoiding undesired dominant-negative effects. After transfection of E14 embryonic stem cells with the linearized targeting vector a total of 35 clones (19\% of clones selected) harbouring the desired mutation were identified. Diagnostic Southern blotting with $5^{\prime}$ and $3^{\prime}$ external probes showed the predicted 10.4 and 8.5 plus $4 \mathrm{kbp} E c o$ RI fragments associated with the wild-type and mutant alleles, respectively, indicating that correct homologous recombination events had indeed occurred at both sides of the disruption in all clones (Fig. 2D).

\subsection{Generation and characterisation of mutant mice}

Six targeted clones were used to generate male chimaeras and germline transmission was achieved for two clones. The highest transmitting line was chosen for heterozygous intercrossings to obtain mice with disruptions of both ScCKmit alleles. Litter sizes were normal and genotyping of offspring by PCR analysis (Fig. 2E) showed the expected Mendelian distribution of wild-type mice and heterozygotes and null mutants. ScCKmit $[-/-]$ mutant mice appeared healthy and displayed no gross abnormalities, behavioral defects or impaired reproductivity. To verify that the gene disruption had indeed created a null mutation. the expression of ScCKmit in skeletal and cardiac muscle was examined. Northern blot hybridization with the deleted $400 \mathrm{bp}$ fragment, covering part of exon three, showed no $1.6 \mathrm{~kb} \mathrm{ScCKmit}$ mRNA product in homozygous mutant mice, while levels in the heterozygotes were approximately half of those expressed in wild types (Fig. 2F). However, a ScCKmit CDNA probe spanning parts of exons 3-4 hybridized to a smaller sized $(1.5 \mathrm{~kb})$ mRNA product. Since a similar product was seen by a ScCKmit cDNA probe spanning exons 6-8 (not shown) we surmise that this mRNA product is derived from the aberrant splicing of mutant transcripts that initiate somewhere in the hygroB gene, but the exact nature of this remnant $\mathrm{mRNA}$ was not investigated further. Hybridization of the RNA blot with a cDNA probe specific for the 5' UTR in mRNA for mouse ubiquitous CKmit (UbCKmit, see for details Steeghs et al., 1995b) detected no UbCKmit mRNA transcripts in total RNA preparations of ScCKmit deficient cardiac or skeletal muscle (Fig. 2F). This suggests that expression of the other mitochondrial CK isoform is not upregulated to detectable levels to compensate for ScCKmit deficiency.

The levels of expression of ScCKmit protein subunits were examined by Western-blot analysis, using a rabbit polyclonal anti-ScCKmit antisenum that was raised against a conserved peptide comprising amino acids $98-114$ of the mature polvpeptide (Friedman and Perryman. 1991). This 
protein segment is encoded by parts of exons 5 and 6 , and is thus located carboxy-terminal from the region that was deleted by homologous recombination. As anticipated, no protein was detectable in cardiac and skeletal muscle lysates from homozygous mutant animals (Fig. 1G) indicating that the residual mRNA transcript cannot encode any stable protein product. When the blots were subsequently incubated with a polyclonal antibody raised against a short unique peptide in the UbCKmit isoform subunit (Friedman and Perryman, 1991) approximately equally weak signal intensities were seen in both muscle tissues in wild-type, heterozygous, and ScCKmit $[-/-]$ mice (Fig. 2G) confirming the findings with Northem blot analysis. CK activities in heart and skeletal muscle extracts were determined biochemically and found to represent approx. 60 and $95 \%$, respectively, of activities in wild-type muscles. These values are mainly attributable to the presence of $\mathrm{M}-\mathrm{CK}$ isoenzyme in sarcoplasm, and include the low levels of B-CK and UbCKmit isoenzymes which originate from vascular smooth muscle or satellite cells in skeletal muscles (Payne et al., 1991).

\subsection{Is there a role for ScCKmit in control of respiratory rate and levels of high energy phosphoryl metabolites?}

Regulation of OXPHOS activity and oxygen consumption in muscle cells is controlled by complex interactions among metabolic pathways in which $\mathrm{Cr}$ levels and CKmit activity may be important parameters (Wyss et al., 1992). However, as shown in Table 1, specific activities of two mitochondrial marker enzymes, cytochrome $c$ oxidase (COX) and citrate synthase (CS), were essentially similar in wild-type and ScCKmit $[-/-]$ heart and hind limb muscles. Furthermore, neither the mitochondrial capacity to oxidize pyruvate in the presence of malate, the resulting high-energy phosphoryl production (measured as the ${ }^{14} \mathrm{CO}_{2}$ derived from oxidation of $\left[1-{ }^{14} \mathrm{C}\right]$ pyruvate, and the arsenite-sensitive mitochondrial generation of ATP + PCr, respectively), nor the ADP stimulation rates in supernatants or isolated mitochondria were compromised by the ScCKmit knock-out mutation. One of the postulated functions of soluble CKs is to keep the cellular ATP pool highly charged and to prevent large fluctuations in the overall ATP / ADP ratio. Therefore, chemical methods were used to examine whether ScCKmit or total CK deficiency had influenced the levels of energy related metabolites in muscles at rest (Table 2). Levels of all metabolites in ScCKmit $[-/-]$ muscles were similar to wild-type values.

\subsection{Changes in profiles of contractile proteins}

We considered the possibility that $\mathrm{CK}$ mutations would bring about an altered response to workload in muscle. As alterations in myosin heavy chain isotype (MHC) distribution are often indicative for activity changes or for regenerative processes (Pette and Vrbová, 1992; Sweeney et al., 1988) MHC typing was performed by gradient gel electrophoresis of muscle extracts under denaturing conditions. Comparison of the distribution patterns in the representative slow soleus muscle, the intermediate type gastrocnemius (Fig. 3A) and diaphragm muscle, and the fast psoas and extensor digitorum longus (EDL; Fig. 3B) muscle, showed that transitions in isomyosin heavy chain types do not occur in either of these types of muscle in ScCKmit $[-/-]$ mice.

Table 1

Activities of mitochondrial enzymes and oxidative phosphorylation characteristics in hind limb and cardiac muscle of wild-type and ScCKmit $-/-]$ mice

\begin{tabular}{|c|c|c|c|c|}
\hline & \multicolumn{2}{|l|}{$600 \times g$ supernatant } & \multicolumn{2}{|c|}{ Isolated mitochondria } \\
\hline & Wild-type & ScCKmit $[-/-1$ & Wild-type & ScCKmit $[-/-]$ \\
\hline \multicolumn{5}{|c|}{ COX activity } \\
\hline Muscle & $353 \pm 76(9)$ & $320 \pm 64(11)$ & $5570 \pm 1388(6)$ & $5306 \pm 2251(5)$ \\
\hline Heart & $955 \pm 303(13)$ & $1127 \pm 424(13)$ & $9324 \pm 3646(6)$ & $9145 \pm 2655(6)$ \\
\hline \multicolumn{5}{|c|}{ CS activity } \\
\hline Muscle & $69 \pm 15(9)$ & $63 \pm 12(11)$ & $861 \pm 274(6)$ & $902 \pm 383(5)$ \\
\hline Heart & $236 \pm 57(13)$ & $263 \pm 72(13)$ & $1007 \pm 161(6)$ & $1132 \pm 150(6)$ \\
\hline \multicolumn{5}{|c|}{${ }^{14} \mathrm{CO}_{2}$ production } \\
\hline Muscle & $2.13 \pm 1.14(11)$ & $1.97 \pm 1.02(8)$ & $2.47 \pm 0.50(6)$ & $1.79 \pm 0.75(5)$ \\
\hline Heart & $1.39 \pm 0.59(10)$ & $1.41 \pm 0.63(10)$ & $0.77 \pm 0.27(5)$ & $0.60 \pm 0.21(4)$ \\
\hline \multicolumn{5}{|c|}{ ATP + PCr Production } \\
\hline Muscle & $26.3 \pm 7.1(11)$ & $27.1 \pm 8.5(8)$ & $30.7 \pm 3.2(4)$ & $23.7 \pm 4.4(4)$ \\
\hline Heart & $14.3 \pm 4.7(8)$ & $15.2 \pm 4.9(8)$ & $17.9 \pm 3.5(4)$ & $12.1 \pm 3.7(3)$ \\
\hline \multicolumn{5}{|c|}{ ADP stimulation } \\
\hline Muscle & $3.1 \pm 0.8(8)$ & $3.5 \pm 1.3(5)$ & $4.5 \pm 0.7(5)$ & $5.4 \pm 1.3(5)$ \\
\hline Heart & $3.5 \pm 1.0(10)$ & $3.3 \pm 0.8(10)$ & $4.0 \pm 0.6(5)$ & $2.7 \pm 0.3(4)$ \\
\hline
\end{tabular}

Values are means \pm SD (number of experiments). N.D., not determined. Activities of cytochrome $c$ oxidase (COX) and citrate synthase (CS) are in $\mathrm{mU} / \mathrm{mg}$ protein; ${ }^{14} \mathrm{CO}_{2}$ and ATP $+\mathrm{PCr}$ production is expressed in $\mu \mathrm{mol} / \mathrm{h}$ per $\mathrm{U} \mathrm{CS}$. ADP stimulation expresses the difference in ${ }^{14} \mathrm{CO}_{2}$ production with and without addition of ADP. 

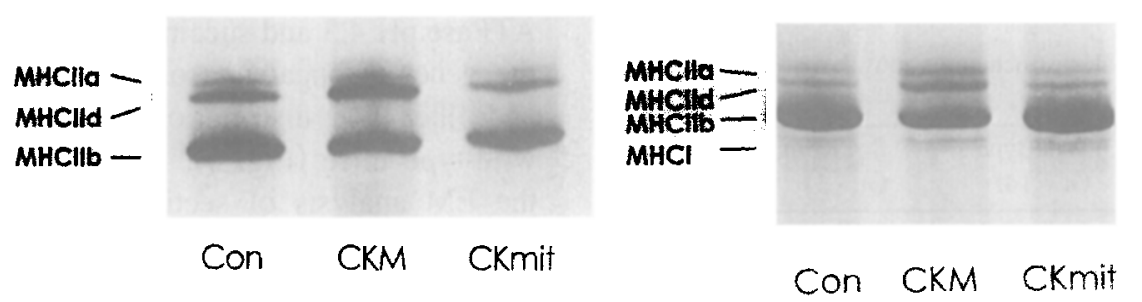

Fig. 3. Myosin heavy chain (MHC) distribution in extracts from $\mathrm{m}$. extensor digitorum longus (EDL) and gastrocnemius muscles of a wild-type and ScCKmit[ $\left.-f_{-}\right]$mouse. Electrophoretic separations on gradient polyacrylamide electrophoresis and silver stainings were performed according to Hämäläinen and Pette (1993). The positions of type I and Il specific MHC isoforms are indicated to the left of each panel.

\subsection{Characterization of skeletal muscle of CK mutant mice by ${ }^{31}$ P-NMR spectroscopy}

Since the phosphorylated metabolites directly measured by in vivo ${ }^{31} \mathrm{P}-\mathrm{NMR}$ are intimately related to the $\mathrm{CK} / \mathrm{PCr}$ system, this technique is most suitable to study the role of $\mathrm{CK}$ enzymes in energy conversion processes in intact resting and working muscle. Therefore, in vivo ${ }^{31} \mathrm{P}-\mathrm{NMR}$ spectroscopy of intact hindlimb muscle of anaesthetized ScCKmit $[-/-]$ and $\mathrm{CK}[-/-]$ mice at rest was performed. To determine the relative levels of NMR-visible energy metabolites at rest, fully relaxed ${ }^{31} \mathrm{P}-\mathrm{NMR}$ spectra

Table 2

Concentrations of energy-related metabolites in leg muscle of CK mutant mice

\begin{tabular}{lcc}
\hline & Wild-type & ScCKmit - / ] \\
\hline$P_{i}$ (NMR) & $5.6 \pm 0.9$ & $4.8 \pm 0.8$ \\
PCr (NMR) & $46.5 \pm 1.3$ & $46.9 \pm 0.7$ \\
PCr (chem) & $62.1 \pm 2.2$ & $64.9 \pm 2.8$ \\
Cr (chem) & $31.9 \pm 2.2$ & $29.1 \pm 2.8$ \\
PCr/Cr (chem) & $1.96 \pm 0.20$ & $2.26 \pm 0.32$ \\
$\alpha-A T P$ (NMR) & $16.7 \pm 0.9$ & $17.5 \pm 0.7$ \\
B-ATP (NMR) & $15.4 \pm 0.5$ & $15.5 \pm 0.8$ \\
$\gamma-A T P$ (NMR) & $14.1 \pm 0.8$ & $14.5 \pm 1.1$ \\
Mean ATP (NMR) & $15.4 \pm 0.3$ & $15.8 \pm 0.4$ \\
ATP (chem) & $24.5 \pm 4.8$ & $22.9 \pm 2.0$ \\
PCr/ATP (NMR) & $3.03 \pm 0.15$ & $2.96 \pm 0.08$ \\
PCr/ATP (chem) & $2.63 \pm 0.57$ & $2.85 \pm 0.24$ \\
$P_{i} /$ PCr (NMR) & $0.12 \pm 0.02$ & $0.10 \pm 0.02$ \\
PMF & $2.7 \pm 0.7(4)$ & $2.9 \pm 0.2(2)$ \\
\hline
\end{tabular}

The concentrations of various energy metabolites were either determined by chemical analysis of snap-frozen medial gastrocnemius muscle or calculated from the relative peak areas (fraction of total integral) of phosphate metabolites in fully relaxed NMR spectra of whole hind limb skeletal muscle of wild-type and CK-mutant mice. Values from chemical quantitation are mean $\pm S D$, indicated in $\mu$ mol per $g$ dry weight. In order to diminish variations mainly caused by the variable presence of nonmuscle constituents in the dry tissue powder, $\mathrm{Cr}$ and $\mathrm{PCr}$ concentrations were normalized for the mean total $\mathrm{Cr}+\mathrm{PCr}$ content of all muscles. NMR spectral values are calculated as mean $\pm \mathrm{SD}$, indicated in $\%$ of the total integral. Mean ATP is the average of the three ATP resonance peaks. Ratios calculated from the chemical determination and NMR measurements are given invididually. The numbers of experiments when the phosphomonoester (PME) signal was clearly above the noise level are given within parentheses. The total number of determinations was $n=6$ for wild-type and CK[- $-1-], n=5$ for M-CK[ $[-/-]$ animals, and $n=4$ or $n=6$ for chemical determination, or NMR determination of ScCKmit[ $--/-1$ animals, respectively. were acquired. Relative peak areas of energy metabolites in wild-type and ScCKmit $-1-]$ single mutants in the spectra from hindlimb muscles showed no differences (Table 2, Fig. 4). Also, flux studies (see Van Deursen et al., 1993) revealed no abnormalities as the forward $\left(K_{\mathrm{f}}\right)$ and reverse $\left(K_{\mathrm{r}}\right)$ pseudo-first order rate constants for the high-energy phosphate transfers between ATP and $\mathrm{PCr}$ were $0.39 \pm 0.08$ and $1.19 \pm 0.28 \mathrm{~s}^{-1}$, respectively $(n=4)$ for ScCKmit $[-/-]$ muscle, similar to the values of rate constants in wild-type muscle (Van Deursen et al., 1993). Finally, $\mathrm{pH}$ calculations yield similar values for wild-type $(7.29 \pm 0.07)$ and $\mathrm{ScCKmit}$ mutants muscles $(7.17 \pm 0.05)$.

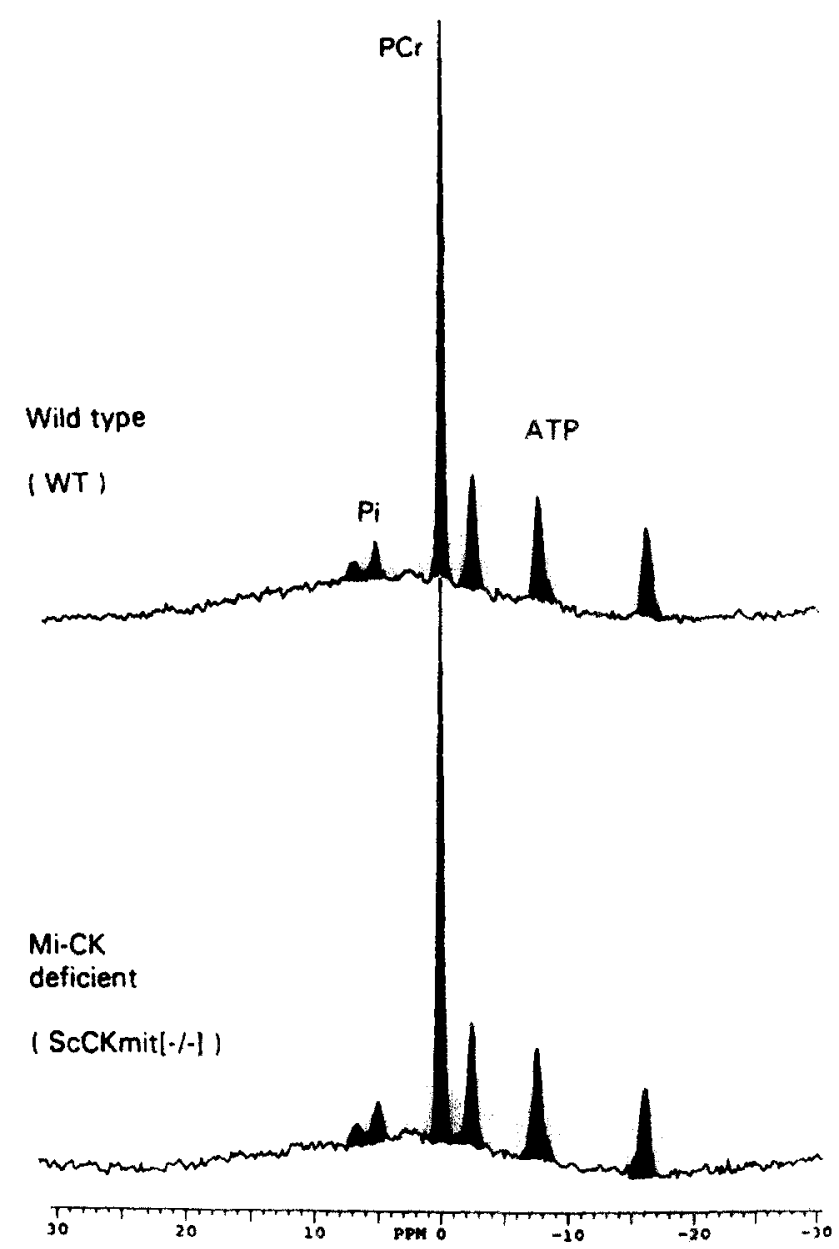

Fig. 4. ${ }^{31}$ P-NMR spectra of phosphate metabolites in lower hind limb musculature of wild-type and ScCKmit $-{ }_{-}$mice at rest. 
Table 3

Force characteristics of medial gastrocnemius muscles of wild-type and ScCKmit $-/-]$ mice

\begin{tabular}{lll}
\hline & $\begin{array}{l}\text { Wild-type } \\
(n=14)\end{array}$ & $\begin{array}{l}\text { ScCKmit }[-/-] \\
(n=5)\end{array}$ \\
\hline Twitch force (N) & $0.19 \pm 0.05$ & $0.17 \pm 0.03$ \\
Tetanic force (N) & $0.82 \pm 0.22$ & $0.78 \pm 0.19$ \\
Tetanic/twitch ratio & $4.26 \pm 0.36$ & $4.57 \pm 0.40$ \\
Time to peak force (ms) & $142 \pm 4$ & $142 \pm 4$ \\
Half relaxation time (ms) & $5.0 \pm 0.5$ & $5.0 \pm 0.5$ \\
\hline
\end{tabular}

Surprisingly, the flux of reversible high energy phosphoryl transfer between $\mathrm{PCr}$ and ATP in 1 and $5 \mathrm{~Hz}$ stimulated muscle was also apparently normal (data not shown).

\subsection{ScCKmit - / - muscles have normal force and relax- ation characteristics}

To test whether the defects in the $\mathrm{CK} / \mathrm{PCr}$ system would influence the excitation-contraction process, muscles of wild-type and ScCKmit mutant mice were subjected to high-intensity exercise protocols to study force generation under conditions of high metabolic flux. In all experiments, contractile performances of ScCKmit [-/- ] muscles were similar to those of wild-type muscles. There was no difference in maximal twitch force between the four groups of mice, or in the time-to-peak or half-relaxation times of the twitch contractions (Table 3).

\subsection{Light microscopical and ultrastructural analyses of abnormalities in ckl- $/-1$ muscles}

Cross-sections from various muscles were stained with hematoxylin/eosin, and assayed histochemically for
ATPase $\mathrm{pH} 4.3$ and succinate dehydrogenase activity. Both the general appearance of stainings, as well as the sizes and fiber-type distributions were similar in mutant and wild-type mice (Fig. 5). Also at the ultrastructural level, the EM analysis of sections of diaphragm, heart, intercostal, gastrocnemius and soleus muscles of 7-14-week-old ScCKmit $[-/-]$ mice revealed no distinct morphological abnormalities in either the myofibrillar compartment or the mitochondrial ultrastructure, i.e., the arrangement of outer and inner mitochondrial membranes and cristae. This is in marked contrast to the finding of enlarged intermyofibrillar mitochondrial volume that was apparent in type 2 (fast) fibers of M-CK deficient GPS muscles (Van Deursen et al., 1993) upon light- and electron-microscopical analyses.

\section{Discussion and conclusions}

\subsection{Mitochondrial creatine kinase deficiency has no overt phenotypic consequences}

The complete absence of biochemical, physiological and ultrastructural consequences of single gene knock-out in our ScCKmit mutant animals is indeed surprising and suggests that escape routes in the elaborate energy transmitting kinase network at the mitochondrial surface may help in masking the loss of ScCKmit activity. Strikingly, no compensatory increase in the levels of mitochondrial marker enzymes, as often seen in human mitochondrial myopathies (Brown and Wallace, 1994), or any significant alterations in the phosphorylation index were observed. Obviously, ATP synthesized by mitochondria can (and most likely also does) reach the cytoplasmic compartment
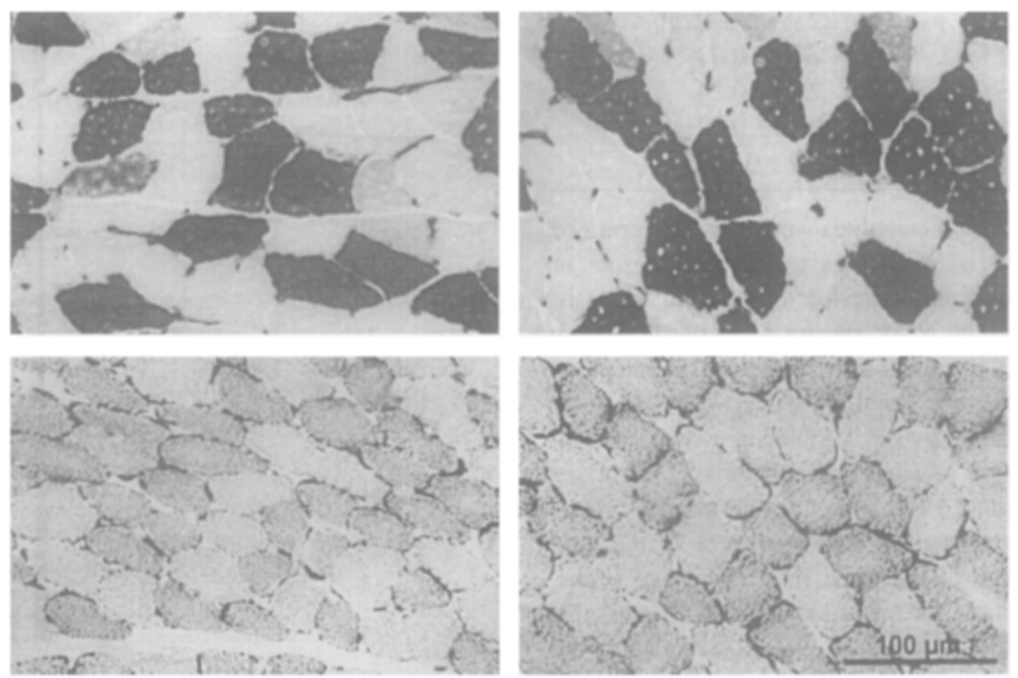

Fig. 5. Cross-sections of soleus and gastrocnemius muscles of wild-type and ScCKmit mutant mice stained for ATPase pH 4.3 (top) and succinate dehydrogenase activity (bottom). Wild-type muscles are shown to the left, ScCKmit deficient muscles are to the right. Note the equal size and fiber-type (I, dark; II, pale) distribution in the ATPase pH 4.3 staining. In the SDH staining equal fiber sizes and similarity in the distribution of type Ila (fast, oxidative; dark) and IIb (fast, glycolytic; pale) fibers are evident. 
independently of the ScCKmit reaction. Whether in this situation the full rate of $\mathrm{PCr}$ production proceeds via the catalytic conversion by cytosolic MMCK, or whether a specific relocation of MMCK to sites in the immediate vicinity of mitochondria ameliorates the effects, remains a subject for further study. NMR studies did shed some light on this issue. Standard spin inversion transfer experiments indicate no abnormality for $\mathrm{PCr} \Leftrightarrow$ ATP exchange in hind leg muscle of ScCKmit [-/-] mice. In contrast, preliminary data of saturation transfer on isolated ScCKmit $[-/-]$ hearts in Langendorff perfusion did show a significantly reduced transfer (K. Nicolay, personal communication). These differential findings may either directly reflect the differences in ScCKmit content (see Fig. 2F,G), or point to the existence of a pool of ATP at the mitochondrial compartment with properties requiring a different NMR magnetization transfer technique for their detection in these tissues (Zahler et al., 1987).

Likewise, in our studies of twitch force, tetanic force, force during repeated isometric contractions, or half relaxation times we may have missed specific physiological manifestations because more adequate protocols must be designed to challenge the enzymatic network involved in aerobic long-term muscle performance sufficiently. The possibility thus remains that a critical low threshold in oxidative energy production may only be reached at more advanced ages when the usual progressive decrease in mitochondrial electron transport capacity would add to the CKmit deficiency. Yet, based on our data thus far with animals of over 18 months of age, it is fair to conclude that ScCKmit activity is not obligatory for regulation of OXPHOS flux or phosphoryl exchange rates, which in turn determine the contractile properties of muscle tissue.

Our findings are surprising in view of the proposed crucial role of CKmit in the high energy phosphate throughput in the mitochondrial intermembrane space (see Section 1 and Wallimann et al., 1992 for reviews). There is, however, the possibility that 'rewiring' of metabolic pathways at or even within the microcompartments or multienzyme complexes of the mitochondria can take over the role of the ablated CKmit. Mitochondrial adenylate kinase (AKmit or AK2), is a strong candidate as it permanently equilibrates the adenine nucleotides at this location. In the absence of creatine, ADP is produced from AMP and ATP in the intermembrane space by AKmit and this ADP is also preferentially used for oxidative phosphorylation and only partially accessible to extramitochondrial circuits. The AKmit mediated stimulus of oxidative phosphorylation is comparable to, or even higher than, the CKmit mediated increase (Gellerich, 1992; Gellerich et al., 1994). It is therefore tempting to speculate that both shuttles contribute to the ATP/ADP conversions at the mitochondrial site (Savabi, 1994). Bessmann and Carpenter (1985) suggested the existence of a tetrahedral arrangement of one molecule of CKmit with two molecules of AKmit clustered around the ANT. Indeed, direct transfer of the $\beta$-phosphate of ATP to creatine (Yang et al., 1977) indicates a close association between these enzymes (see also Zeleznikar et al., 1995).

In summary, our results show that muscular function is not absolutely dependent on presence of CKmit. Although we have not challenged the energy system under extreme conditions such as anoxia (Miller, 1993) or high-work performance we surmise that - as in many other KO mutant mouse models - the mild phenotype may result from spreading or dilution effects (i.e., flux redirection) in a complex cellular network. There are many reasons to believe that energy homeostasis is such a complex network and therefore further ablation of genes for essential components other than CKs will be necessary to unveil the distinct biochemical and physiological functions of the $\mathrm{CK} / \mathrm{PCr}$ system in the mitochondrial compartment.

\section{References}

Adams, V., Bosch, W., Schlegel, J., Wallimann, T. and Brdiczka, D. (1989) Further characterization of contact sites from mitochondria of different tissues: Topology of peripheral kinases, Biochim. Biophys. Acta, 981: 213-225.

Balaban, R.S. (1990) Regulation of oxidative phosphorylation in the mammalian cell, Am. J. Physiol., 258: C377-C389.

Bessmann, S.P. and Carpenter, L.C. (1985) The creatine-creatine phosphate energy shuttle, Annu. Rev. Biochem. 54, 831-862.

Biermans, W., Bakker, A. and Jacob, W. (1990) Contact sites between inner and outer mitochondrial membrane: A dynamic microcompartment for creatine kinase, Biochim, Biophys. Acta, 1018: 225-228.

Blum, H., Balschi, J.A. and Johnson, R.G. (1991) Coupled in vivo activity of creatine phosphokinase and the membrane-bound $\left(\mathrm{Na}^{+} / \mathrm{K}^{+}\right)$-ATPase in the resting and stimulated organ of the electric fish Narcine brasiliensis, J. Biol. Chem., 266: 10254-10259.

Brdiczka, D. (1991) Contact sites between mitochondrial envelope membranes. Structure and function in energy- and protein transfer, Biochim Biophys. Acta, 1071: 291-312.

Brdiczka, D. and Wallimann, T. (1994) The importance of the outer mitochondrial compartment in regulation of energy metabolism, Mol. Cell. Biochem. 133/134: 69-83.

Bradley, A. (1987) Production and analysis of chimeric mice. In E.J. Robertson (Ed.), Teratocarcinomas and Embryonic Stem Cells: A Practical Approach, IRL Press, Oxford, pp. 113-151.

Brandon, E.P., Idzerda, R.L. and McKnight, G.S. (1995) Targeting the mouse genome: A compendium of knockouts, Curr. Biol. 5, 625, 758, 873.

Brown, M.D. and Wallace, D.C. (1994) Molecular basis of mitochondrial DNA disease, J. Bioenerg. Biomembr. 26, 273-289.

Brosnan, M.J., Chen, L., VanDyke, T.A. and Koretsky, A.P. (1990) Free ADP levels in transgenic mouse liver expressing creatine kinase: effects of enzyme activity, phosphagen type, and substrate concentration, J. Biol. Chem., 265: 20849-20855.

Brosnan, M.J., Raman, S.P., Chen, L. and Koretsky, A.P. (1993) Altering creatine kinase isoenzymes in transgenic mouse muscle by overexpression of the B subunit, Am. J. Physiol., 264: C151-C160.

Capecchi, M.R. (1989) The new mouse transgenetics: altering the genome by gene targeting, Trends Genet., 5: 70-76.

Cooperstein, S.J. and Lazarow, A. (1951) A microspectrophotometric method for the determination of cytochrome oxidase, J. Biol. Chem. $189,665-680$.

De Haan, A., Jones, D.A. and Sargeant, A.J. (1989) Changes in velocity 
of shortening, power output and relaxation rate during fatigue of rat medial gastrocnemius, Pflügers Arch. 413, 422-428.

Dunnett, M., Harris, R.C. and Orme, C.E. (1991) Reverse-phase ion-pairing high-performance liquid chromatography of phosphocreatine, creatine and creatinine in equine muscle, Scand. J. Clin. Lab. Invest. 51, $137-141$.

Edwards, R.H.T., Hill, D.K. and Jones, D.A. (1975) Metabolic changes associated with the slowing of relaxation in fatigued mouse muscle, $J$. Physiol. 251, 287-301.

Erecinska, M. and Wilson, D. (1982) Regulation of cellular energy metabolism. J. Membr. Biol., 70: 1-14.

Evans, M.J. (1989) Potential for genetic manipulation of mammals, Mol. Biol. Med., 6: 557-565.

Fischer, J.C., Ruitenbeek, W., Gabreëls, F.J.M., Janssen, A.J.M., Renier, W.O., Sengers, R.C.A., Stadhouders, A.M., Ter Laak, H.J., Trijbels, J.M.F. and Veerkamp, J.H. (1986) A mitochondrial encephalomyopathy: the first case with an established defect at the level of coenzyme Q. Eur. J. Pediatr., 144: 441-444.

Friedhof, A.J. and Lemer, M.H. (1977) CK isoenzyme association with synaptosomal membrane and synaptic vesicles, Life Sci., 20: 867-872.

Friedman, D.L. and Perryman, M.B. (1991) Compartmentalization of multiple forms of creatine kinase in the distal nephron of the rat kidney, J. Biol. Chem., 266: 2240422410.

Friedman, D.L. and Roberts, R. (1994) Compartmentalization of braintype creatine kinase and ubiquitous mitochondrial creatine kinase in neurons: evidence for a creatine phosphate energy shuttle in adult rat brain, J. Comp. Neurol., 343: 500-511.

Gellerich, F.N. (1992) The rolc of adenylate kinase in dynamic compartmentalization of adenine nucleotides in the mitochondrial intermembrane space, FEBS Lett., 297: 55-58.

Gellerich, F.N., Kapischke. M., Kunz, W., Neumann, W., Kuznetsov, A., Brdiczka, D. and Nicolay, K. (1994) The influence of the cytosolic oncotic pressure on the permeability of the mitochondrial outer membrane for ADP: implications for the kinetic properties of mitochondrial creatine kinase and for ADP channeling into the intermembrane space, Mol. Cell. Biochem., 133/134: 85-104.

Grosse, R., Spitzer, E., Kupriyanov, V.V., Saks. V.A. and Repke, K.R.H. (1980) Coordinate interplay between $\left(\mathrm{Na}^{+} / \mathrm{K}^{+}\right)$-ATPase and $\mathrm{CK}$ optimizes $\left(\mathrm{Na}^{+} / \mathrm{K}^{+}\right)$-antiport across the membrane of vesicles formed from the plasma membrane of cardiac muscle cells, Biochim. Biophys. Acta, 603: 142-156.

Haas, R.C., Korenfeld, D.C., Zhang,.Z., Perryman, M.B., Roman, D. and Strauss, A.W. (1989) Isolation and characterization of the gene and CDNA encoding human mitochondrial creatine kinase, J. Biol. Chem., 264: 2890-2897, 16332 (correction).

Hämäläinen, N. and Pette, D. (1993) The histochemical profiles of fast fiber types IIB, IID, and IIA in skeletal muscles of mouse, rat, and rabbit, J. Histochem. Cytochem. 41, 733-743.

Heerschap, A., Bergman, A.H., Vaals, J.J., Wirtz, P., Loermans, H.M.T. and Veerkamp, J.H. (1988a) Alterations in relative phosphocreatine concentrations in preclinical mouse muscular dystrophy revealed by in vivo NMR, NMR Biomed. 1, 27-31.

Heerschap, A., Van Vaals, J.J., Bergman, A.H., Den Boer, J.H., Van (jerwen, P.H.J. and Gravenmade, E.J. (1988b) In vivo ${ }^{31}$ P-NMR studies of rat salivary glands. Magn. Reson. Med. 8, 129.

Hemmer, W. and Wallimann, T. (1993) Functional aspects of creatine kinase in brain, Dev. Neurosci., 15: 249-260.

Hemmer, W.. Zanolla, E., Furter-Graves, E.M., Eppenberger, H.M. and Wallimann, T. (1994) Creatine kinase isoenzymes in chicken cerebellum: specific localization of brain-type creatine kinase in Bergmann glial cells and muscle-type creatine kinase in Purkinje neurons, Eur. J. Neurosci., 6: $538-549$.

Hossle, J.P., Schlegel, J., Wegmann, G., Wyss, M., Böhlen, P., Eppenberger. H.M., Wallimann, T. and Perriard, J.-C. (1988) Distinct tissue-specific mitochondrial creatine kinases from chicken brain and siriated muscle with a conserved CK framework, Biochem. Biophys. Res. Commur., 151: 408-416.
Ikeda, K. (1988) Localization of brain type creatine kinase in kidney epithelial cell subpopulations in rat, Experientia, 44: 734-735.

Ishida, Y., Rjesinger, T., Wallimann, T. and Paul, R.J. (1994) Compartmentalization of ATP synthesis and utilization in smooth muscle: roles of aerobic glycolysis and creatine kinas. Mol. Cell. Biochem. 133/134: 39-50.

Jacobus, W.E. and Lehninger, A.L. (1973) Creatine kinase of rat heart. mitochondrial coupling of creatine phosphorylation to electron trans. port. J. Biol. Chem., 248: 4803-4810.

Jaenisch. R. (1988) Transgenic animals, Science, 240). 1468-1474.

Jones, D.P. (1986) Intracellufar diffusion gradients of $Q$, and ATP, Am. J. Physiol., 250: C663-C675.

Joyner, A.L. (1991) Gene targeting and gene trap screens using embryonic stem cells: new approaches to mammalian development, Bioessays, 13: 649-656.

Knoll, G. and Brdiczka, D. (1983) Changes in freeze-fracture mitochondrial membranes correlated to their energetic state. Biochim. Biophys. Acta, 733: 102-110

Koretsky, A.P., Brosnan, M.J., Chen, L., Chen, I. and VanDyke, T. (1990) NMR detection of creatine kinase expressed in liver of transgenic mice: determination of free ADP levels. Proc. Natl. Acad. Sci. USA, 87, $3112-3116$

Korge, P. and Campbell, K.B. (1994) Local ATP regeneration is important for sarcoplasmic reticulum $\mathrm{Ca}^{2+}$ pump furction. Am. J. Physiol. 267: C357-C 366 .

Levitsky, D.O., Levchenko, T.S., Saks, V.A., Sharov, V.G. and Sminov, V.N. (1978) The role of creatine phosphokinase in supplying energy for the calcium pump system of heart sarcoplasmic reticulum, Membr. Biochem., 2: 81-96.

Lim, L.. Hall, C., Leung, T., Mahadevan, L. and Whatley, S. (1989) Neurone-specific enolase and creatine phosphokinase are protein components of rat brain synaptic plasma membranes, J. Neurochem., 41:1177-1182.

Lipskaya, T.Yu. and Trofimova, M.E. (1989) Study on heart mitochondrial creatine kinase using a cross-linking bifunctional reagent. I. The binding involves the octameric form of the enryme. Biochem Int., 18: $1029-1039.1149-1159$.

Miller, D.S. and Horowitz. S.B. (1986) Intracellular companmentalization of adenosine triphosphate, J, Biol. Chem., 261: $13911-13915$.

Miller, K., Halow, J. and Koretsky, A.P. (1993) Phosphocreatine protects transgenic mouse liver expressing creatine kinase from hypoxia and ischemia. Am. J. Physiol., 265: C1544-Cl551

Mühlebach, S.M., Gross, M., Wirz, T., Wallimann, I.. Perriard, J.-C. and Wyss, M. (1994) Sequence homology and structure predictions of the creatine hinase isoenzymes. Mol. Cell. Biochem. 133/134: 245-262.

Payne, R.M., Haas, R.C. and Strauss, A.W. (1991) Structural characterization and tissue-specific expression of the mRNAs encoding isoenzymes from two rat mitochondrial creatine kinase genes, Biochim. Biophys. Acta, 1089: 352-361.

Perriard, J.-C.. Perriard. E.R. and Eppenberger, H.M. (1989) Detection and relative quantitation of mRNA for creatine kinase isoenzymes in RNA from myogenic cell cultures and embryonic chicken tissues. J. Biol. Chem.. 253: 6529-6535.

Pette, D. and Vrbová, G. (1992) Adaptation of matmmalian skeletal muscle fïhers to chronic electrical stimulation. Rev. Physiol. Biochem. Pharmacol. 120.115-202

Reichenbach. A. (1991) Glial $\mathrm{K}^{+}$permeability and CNS K" clearance by diftusion and spatial buffering. In N.J. Abbott (Ed.), Glial-Neuronal Interation. New York Academy of Sciences. New York, pp. 272-286

Rojo, M., Hovius, R., Demel, R.A., Nicolay, K. and Wallimann, T. (1991) Mitochondrial creatine kinase mediates contact formation between mitochondrial membranes, J. Biol. Chem.. 266: 20290-20295.

Rossant. J. (i991) Gene disruption in mammals, Cur, Opin. Genet. Dev.. 1: $236-2.40$.

Rossi, A.M., Eppenberger, H.M., Vopie, P.. Cotrufo. R. and Wallimarn. T. (1990) Muscle-type MM creatine kinase is specitically bound to 
sarcoplasmic reticulum and can support $\mathrm{Ca}^{2+}$ uptake and regulate local ATP/ADP ratios, J. Biol. Chem., 265: 5258-5266.

Saks, V.A., Chemousova, G.B., Vetter, R., Smimov, V.N. and Chazov, E.I. (1976) Kinetic properties and the functional role of particulate MM-isoenzyme of creatine phosphokinase bound to heart muscle myofibrils, FEBS Lett., 62: 293-296.

Saks, V.A., Lipina, N.V., Sharov, V.G., Smirnov, V.A., Chazov, E.I. and Grosse, R. (1977) The localization of MM-isoenzyme of creatine kinase on the surface membrane of myocardial cells and its functional coupling to ouabain-inhibited $\mathrm{Na}^{+} / \mathrm{K}^{+}$ATPase, Biochim. Biophys. Acta, 465: 550-558.

Saks, V.A., Khuchua, Z.A., Vasilyeva, E.V., Belikova, O.Yu. and Kuznetsov, A.V. (1994) Metabolic compartmentalization and substrate channeling in muscle cells. Role of coupled creatine kinases in in vivo regulation of cellular respiration - a synthesis, Mol. Cell. Biochem., 133/134: 155-192.

Savabi, F. (1994) Interaction of creatine kinase and adenylate kinase systems in muscle cells, Mol. Cell. Biochem., 133/134: 145-152.

Schlegel, J., Wyss, M., Eppenberger, H.M. and Wallimann, T. (1990) Functional studies with the octameric and dimeric form of mitochondrial creatine kinase, J. Biol. Chem., 265: 9221-9227.

Scopes, R.K. (1973) Studies with a reconstituted muscle glycolytic system -- rate and extent of creatine phosphorylation by anaerobic glycolysis, Biochem. J., 134: 197.

Sellevold, O.F.M., Jynge, P. and Aarstad, K. (1986) High performance liquid chromatography: a rapid isocratic method for determination of creatine compounds and adenine nucleotides in myocardial tissue, J. Mol. Cell. Cardiol., 18, 517-527.

Smithies, O. (1993) Animal models of human genetic diseases, Trends Genet., 9: 112-117.

Srere, P. (1987) Complexes of sequential metabolic enzymes, Annu. Rev. Biochem., 56: 89-124.

Srere, P.A. (1969) Citrate synthase, citrate oxaloacetate lyase, Methods Enzymol., 13: 3-11.

Steeghs, K., Oerlemans, F. and Wieringa, B. (1995a) Mice deficient in ubiquitous mitochondrial creatine kinase are viable and fertile, Biochim. Biophys. Acta, 1230: 130-138.

Steeghs, K., Peters, W., Croes, H., Brückwilder, M., Van Alewijck, D. and Wieringa, B. (1995b) Mouse ubiquitous mitochondrial creatine kinase: gene organization and consequences from inactivation in mouse embryonic stem cells, DNA Cell Biol., 14: 539-553.

Sweeney, H.L., Kushmerick, M.J., Mabuchi, K., Sreter, F.A. and Gergely, J. (1988) Myosin alkali light chain and heavy chain variations correlate with altered shortening velocity of isolated skeletal muscle fibers, J. Biol. Chem., 263: 9034-9039.

Thomas, K.R. and Capecchi, M.R. (1987) Site-directed mutagenesis by gene targeting in mouse embryo-derived stem cells, Cell, 51: 503-512.

Trask, R.V., Strauss, A.W. and Billadello, J.J. (1988) Developmental regulation and tissue-specific expression of the human muscle creatine kinase gene, J. Biol. Chem., 263: 17142-17149.

Turner, D.C., Wallimann, T. and Eppenberger, H.M. (1973) A protein that binds specifically to the $M$-line of skeletal muscle is identified as the muscle form of creatine kinase, Proc. Natl. Acad. Sci. USA, 70: $702-705$.

Van Deursen, J., Schepens, J., Peters, W., Meijer, D., Grosveld, G., Hendriks, W. and Wieringa, B. (1992) Genetic variability of the murine creatine kinase $B$ gene locus and related pseudogenes in different inbred strains of mice, Genomics, 12: 340-349.

Van Deursen, J., Heerschap, A., Oerlemans, F., Ruitenbeek, W., Jap, P., Ter Laak, H. and Wieringa, B. (1993) Skeletal muscles of mice deficient in muscle creatine kinase lack burst activity, Cell, 74: 621-631.

Van Deursen, J., Ruitenbeek, W., Heerschap, A., Jap, P., Ter Laak, H. and Wieringa, B. (1994a) Creatine kinase in skeletal muscle energy metabolism: a study of mouse mutants with graded reduction in M-CK expression, Proc. Natl. Acad. Sci. USA, 91: 9091-9095.

Van Deursen, J., Jap, P., Heerschap, A., Ter Laak, H., Ruitenbeek, W. and Wieringa, B. (1994b) Effects of the creatine analogue $\beta$ guanidinopropionic acid on skeletal muscles of mice deficient in muscle creatine kinase, Biochim. Biophys. Acta, 1185: 327-335.

Veksler, V. and Ventura-Clapier, R. (1994) Ischaemic metabolic factors high inorganic phosphate and acidosis - modulate mitochondrial creatine kinase functional activity in skinned cardiac fibres, J. Mol. Cell. Cardiol., 26: 335-339.

Ventura-Clapier, R., Saks, V.A., Vassort, G., Lauer, C. and Elizarova, G.V. (1987) Reversible MM-creatine kinase binding to cardiac muscle, Am. J. Physiol., 253: C444-C455.

Ventura-Clapier, R., Veksler, V. and Hoerter, J.A. (1994) Myofibrillar creatine kinase and cardiac contraction, Mol. Cell. Biochem., 133/134: 125-144.

Wallimann, T., Wyss, M., Brdiczka, D., Nicolay, K. and Eppenberger, H.M. (1992) Intracellular compartmentalization, structure and function of creatine kinase isoenzymes in tissues with high and fluctuating energy demands: the 'phosphocreatine circuit' for cellular energy homeostasis, Biochem. J., 281: 21-40.

Wegmann, G., Zanolla, E., Eppenberger, H.M. and Wallimann, T. (1992) In situ compartmentalization of creatine kinase in intact sarcomeric muscle: the acto-myosin overlap zone as a molecular sieve, J. Muscle Res. Cell Motil., 13: 420-435.

Wyss, M., Smeitink, J., Wevers, R.A. and Wallimann, T. (1992) Mitochondrial creatine kinase: a key enzyme of aerobic energy metabolism, Biochim. Biophys. Acta, 1102: 119-166.

Yang, W.C.T., Geiger, P.J., Bessman, S.P. and Borrebaek, B. (1977) Formation of creatine phosphate from creatine and ${ }^{32} \mathrm{P}$-labeled ATP by isolated rabbit heart mitochondria, Biochem. Biophys. Res. Commun., 76: 882-887.

Zahler, R., Bittl, J.A. and Ingwall, J.S. (1987) Analysis of compartmentalization of ATP in skeletal and cardiac muscle using ${ }^{31} \mathrm{P}$ nuclear magnetic resonance saturation transfer, Biophys. J. 51, 883-893.

Zeleznikar, R.J., Dzeja, P.P. and Goldberg, N.D. (1995) Adenylate kinase-catalyzed phosphoryl transfer couples ATP utilization with its generation by glycolysis in intact muscle, J. Biol. Chem. 270, 73117319. 